\title{
Vent Fauna in the Mariana Trough
}

\author{
Shigeaki Kojima and Hiromi Watanabe
}

\begin{abstract}
The Mariana Trough is a back-arc basin in the Northwestern Pacific. To date, active hydrothermal vent fields associated with the back-arc spreading center have been reported from the central to the southernmost region of the basin. In spite of a large variation of water depth, no clear segregation of vent faunas has been recognized among vent fields in the Mariana Trough and a large snail Alviniconcha hessleri dominates chemosynthesisbased communities in most fields. Although the Mariana Trough approaches the Mariana Arc at both northern and southern ends, the fauna at back-arc vents within the trough appears to differ from arc vents. In addition, a distinct chemosynthesis-based community was recently discovered in a methane seep site on the landward slope of the Mariana Trench. On the other hand, some hydrothermal vent fields in the Okinawa Trough backarc basin and the Izu-Ogasawara Arc share some faunal groups with the Mariana Trough. The Mariana Trough is a very interesting area from the zoogeographical point of view.

Keywords
$\begin{aligned} & \text { Alvinoconcha hessleri • Chemosynthetic-based communities } \\ & \text { vent • Mariana Arc } • \text { Mariana Trough }\end{aligned}$
\end{abstract}

\subsection{Introduction}

The Mariana Trough is a back-arc basin in the Northwestern Pacific (Fig. 25.1). The present hydrothermal activity in the Mariana Trough is estimated to have started about 7 million years ago (Ma) (Stern et al. 2003) and some dating studies reported records of mineralization in this region since 12,000 years ago (Stüben et al. 1994; Takamasa et al. 2013; Ishibashi et al. Chap. 23).

\section{S. Kojima $(\triangle)$}

Graduate School of Frontier Sciences, The University of Tokyo, Chiba 277-8563, Japan

Atmosphere and Ocean Research Institute, The University of Tokyo, Chiba 277-8564, Japan

e-mail: kojima@aori.u-tokyo.ac.jp

H. Watanabe

Japan Agency for Marine-Earth Science and Technology, Kanagawa 237-0061, Japan
The first hydrothermal vent field discovered in the Mariana Trough was the Alice Springs, in the Central Mariana Trough $\left(18^{\circ} 13^{\prime} \mathrm{N}, 144^{\circ} 43^{\prime} \mathrm{E}: 3,600 \mathrm{~m}\right.$ depth) in 1987 (Craig et al. 1987). Although an unnamed vent field was discovered $20 \mathrm{~km}$ south of the Alice Springs $\left(18^{\circ} 03^{\prime} \mathrm{N}, 144^{\circ} 45^{\prime} \mathrm{E}: 3,660 \mathrm{~m}\right.$ depth), biological research have not yet conducted there (Hessler and Lonsdale 1991). Next vent field was discovered at the Forecast Vent site $\left(13^{\circ} 24^{\prime} \mathrm{N}, 143^{\circ} 55^{\prime} \mathrm{E}: 1,470 \mathrm{~m}\right.$ depth $)$ in 1992 (Johnson et al. 1993). This site has been classified as an arc-related vent (e.g. Embley et al. 2007), however a recent study proposed that volcanic style in the region around the Forecast seamount reflects strong extension in the back-arc basin (Stern et al. 2013). Although the geologic setting of the Forecast site would be considered as in transition, vent fauna of this field is more similar to other vent fields in the Mariana Trough than arc vents as mentioned below, and we treat it as a vent field in the Mariana Trough in this paper.

In the southernmost region of the Mariana Trough, various hydrothermal vent fields have been discovered 


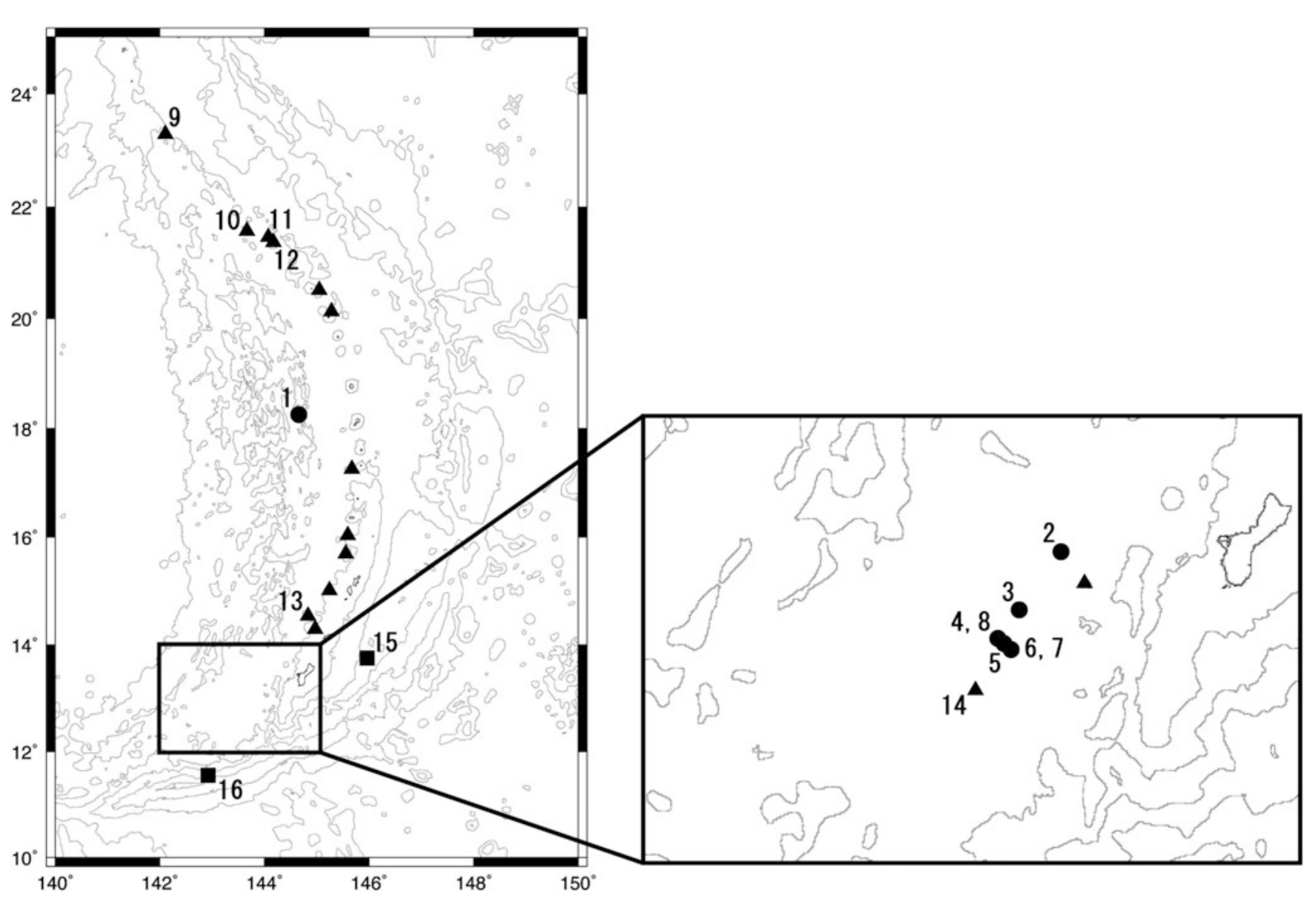

Fig. 25.1 A map of hydrothermal vent fields in the Mariana Trough (closed circles) and the Mariana Arc (Closed triangles), and a methane seep sites in the Mariana Trench (closed squares). Bathymetrical contour intervals are $2,000 \mathrm{~m} .1$, Alice Springs and an unnamed vent field; 2, Forecast Vent site; $3,13^{\circ} \mathrm{N}$ Ridge site; 4, Snail site; 5, Archaean site;

(Yoshikawa et al. 2012). First in this region, a lowtemperature vent site (the $13^{\circ} \mathrm{N}$ Ridge site) was discovered at $13^{\circ} 06^{\prime} \mathrm{N}$ on the Backarc Spreading Center $\left(13^{\circ} 06^{\prime} \mathrm{N}\right.$, $143^{\circ} 41^{\prime} \mathrm{E}, 2,945 \mathrm{~m}$ depth) in 1999 (Mitsuzawa et al. 2000; Masuda et al. 2001b). Thereafter, an active vent field was discovered at the Snail site ( $=$ Fryer site; $12^{\circ} 57^{\prime} \mathrm{N}, 143^{\circ} 37^{\prime} \mathrm{E}$, $2,850 \mathrm{~m}$ depth), which is also situated on the back-arc spreading center, in 2003 (Wheat et al. 2003). The Yamanaka site $\left(=\mathrm{Y}\right.$ site; $12^{\circ} 57^{\prime} \mathrm{N}, 143^{\circ} 37^{\prime} \mathrm{E}, 2,826 \mathrm{~m}$ depth), which is about $1.1 \mathrm{~km} \mathrm{SW}$ of the Snail site, was also discovered on the spreading center in 2003 (Kakegawa et al. 2008). The Pika site $\left(12^{\circ} 55^{\prime} \mathrm{N}, 143^{\circ} 39^{\prime} \mathrm{E}, 2,770 \mathrm{~m}\right.$ depth) and the Archaean site $\left(12^{\circ} 56^{\prime} \mathrm{N}, 143^{\circ} 38^{\prime} \mathrm{E}, 2,990 \mathrm{~m}\right.$ depth) were discovered on off-axis seamounts in 2003 (Urabe et al. 2004; Ishibashi et al. 2004). The newest hydrothermal vent field was discovered at the Urashima site $\left(12^{\circ} 55^{\prime} \mathrm{N}, 143^{\circ} 39^{\prime} \mathrm{E}, 2,922 \mathrm{~m}\right.$ depth$)$, which is situated about $0.5 \mathrm{~km}$ north of the Pika site, in 2010 (Nakamura et al. 2012). The Snail, Archaean, Pika, and Urashima sites are distributed almost on a straight line from ridge axis to the
6, Pika site; 7, Urashima site; 8 , Yamanaka site; 9, Nikko Seamount; 10, Dai-ni (second) Kasuga Seamount; 11, NW Eifuku Seamount; 12, Daikoku Seamount; 13, NW Rota-1 Seamount; 14, TOTO Caldera; 15, South Chamorro Seamount; 16, Shinkai Seep Field

off-ridge, which suggests that the locality of hydrothermal activity is controlled by tectonic fractures.

\subsection{Vent Fauna of the Mariana Trough}

\subsubsection{Research History}

Hessler and Lonsdale (1991) report 30 species from the chemosynthetic communities at the Alice Springs site (Table 25.1). They pointed out faunal affinity at the genus level between vent fields of the Mariana Trough and the central ridges in the Eastern Pacific Ocean, although they stated that eight genera were known only from the western Pacific vents. After 6 years, Fujikura et al. (1997) and Hasegawa et al. (1997) summarized vent faunas at the Alice Springs and Forecast sites based on specimens collected using the submersible SHINKAI 2000 in 1996 (Table 25.1). In spite of a large difference in water depth 
Table 25.1 List of animals collected in hydrothermal vent fields in the Mariana Trough

\begin{tabular}{|c|c|c|c|c|c|c|}
\hline Phylum & Class & Family & Species & Sites $^{\mathrm{a}}$ & Description & Remarks \\
\hline Porifera & Demospongiae & Cladorhizidae & Abyssocladia sp. & 4 & & \\
\hline \multirow[t]{5}{*}{ Cnidaria } & Actinulida & Actinostolidae & Marianactis bythios & 1,2 & $\begin{array}{l}\text { Fautin and Hessler } \\
\text { (1989) }\end{array}$ & \\
\hline & & & Small sea anemone & 1 & & $\begin{array}{l}\text { Hessler and Lonsdale (1991), } \\
\text { photograph only }\end{array}$ \\
\hline & & & White sea anemone & 7 & & Video and photograph only \\
\hline & & & $\begin{array}{l}\text { Actinostolid-like } \\
\text { anemone }\end{array}$ & 4 & & Video and photograph only \\
\hline & & & Anemone & 3,5 & & Video and photograph only \\
\hline Plathyhelminthes & Polycladida & & unidentifid species & 2 & & Fujikura et al. (1997) \\
\hline \multirow[t]{9}{*}{ Annelida } & Polychaeta & Alvinellidae & Paralvinella hessleri & 1 & $\begin{array}{l}\text { Desbruyères and } \\
\text { Laubier (1989) }\end{array}$ & \\
\hline & & Polynoidae & $\begin{array}{l}\text { Branchinotogluma } \\
\text { burkensis }\end{array}$ & 1,2 & Pettibone (1989) & \\
\hline & & Polynoidae & $\begin{array}{l}\text { Branchinotogluma } \\
\text { marianus }\end{array}$ & 1,2 & & $\begin{array}{l}\text { Described as } \\
\text { Opisthotrochopodus } \\
\text { marianus }\end{array}$ \\
\hline & & Lepidonotopodinae & $\begin{array}{l}\text { Lepidonotopodium } \\
\text { minutum }\end{array}$ & 1 & & \\
\hline & & Lepidonotopodinae & Levensteiniella raisae & 1 & & \\
\hline & & Hesionidae & Hesiocaeca hessleri & 1 & Blake (1991) & $\begin{array}{l}\text { Hesiocaeca sp. in Hessler and } \\
\text { Lonsdale (1991) }\end{array}$ \\
\hline & & Maldanidae & Nicomache sp. & 1 & & $\begin{array}{l}\text { Nicomache arwidssoni in } \\
\text { Hessler and Lonsdale (1991); } \\
\text { Nicomache cf. ohtai in } \\
\text { Desbruyères et al. (2006) }\end{array}$ \\
\hline & & Ampharitidae & $\begin{array}{l}\text { Amphisamytha } \\
\text { galapagensis }\end{array}$ & 1 & Zottoli (1983) & \\
\hline & & & unidentified species & 1,2 & & Fujikura et al. (1997) \\
\hline \multirow[t]{13}{*}{ Mollusca } & Aplacophora & Simrothiellidae & undescribed species & 1 & & Hessler and Lonsdale (1991) \\
\hline & Bivalvia & Mytilidae & Bathymodiolus sp. & 1,2 & & $\begin{array}{l}\text { It forms a monophyletic } \\
\text { group with } B \text {. septemdierum, } \\
B . \text { brevior, and } B \text {. marisindicus } \\
\text { (Fujita et al. 2009). }\end{array}$ \\
\hline & & Malletiidae & $\begin{array}{l}\text { undescribed species } \\
\text { (Malletia } \text { sp.?) }\end{array}$ & 2 & & Fujikura et al. (1997) \\
\hline & Gastropoda & Provannidae & Alviniconcha hessleri & $\begin{array}{l}1,2,3 \\
4,5\end{array}$ & $\begin{array}{l}\text { Okutani and Ohta } \\
\text { (1988) }\end{array}$ & \\
\hline & & Provannidae & $\begin{array}{l}\text { Provanna } \\
\text { nassariaeformis }\end{array}$ & 1 & Okutani (1990) & \\
\hline & & Provannidae & $\begin{array}{l}\text { Desbruyeresia } \\
\text { marianaensis }\end{array}$ & 1,2 & & $\begin{array}{l}\text { Described as Provanna } \\
\text { marianaensis }\end{array}$ \\
\hline & & Provannidae & $\begin{array}{l}\text { Desbruyeresia } \text { cf. } \\
\text { mariaensis }\end{array}$ & 4,56 & & \\
\hline & & Provannidae & $\begin{array}{l}\text { Desbruyeresia cf. } \\
\text { spinosa }\end{array}$ & 2 & & Hasegawa et al. (1997) \\
\hline & & Neomphalidae & $\begin{array}{l}\text { Symmetromphalus } \\
\text { regularis }\end{array}$ & 1,2 & McLean (1990) & \\
\hline & & Lepetodrilidae & $\begin{array}{l}\text { Lepetodrilus aff. } \\
\text { schrolli }\end{array}$ & 1,2 & & $\begin{array}{l}\text { L. elevatus in Hessler and } \\
\text { Lonsdale (1991); Johnson et al., } \\
\text { (2008) }\end{array}$ \\
\hline & & Lepetodrilidae & Lepetodrilus sp. & 4 & & \\
\hline & & Phenacolepadidae & Shinkailepas spp. & $\begin{array}{l}1,2,3 \\
4,5,6\end{array}$ & & $\begin{array}{l}\text { Shinkailepas cf. kaikatensis in } \\
\text { Hessler and Lonsdale (1991) } \\
\text { and Fujikura et al. (1997) }\end{array}$ \\
\hline & & Acmaeidae & Undescribed species & 1 & & Hessler and Lonsdale (1991) \\
\hline
\end{tabular}


Table 25.1 (continued)

\begin{tabular}{|c|c|c|c|c|c|c|}
\hline \multirow[t]{11}{*}{ Phylum } & Class & Family & Species & Sites $^{\mathrm{a}}$ & Description & Remarks \\
\hline & & Turridae & $\begin{array}{l}\text { Phymorhynchus cf. } \\
\text { starmeri }\end{array}$ & $1,2,5$ & & $\begin{array}{l}\text { Fujikura et al. (1997), probably } \\
\text { Buccinidae indet. in Hessler and } \\
\text { Lansdale (1991) }\end{array}$ \\
\hline & & Turridae & Phymorhynchus sp. & 3,5 & & \\
\hline & & Clypeosectidae & $\begin{array}{l}\text { Pseudorimula } \\
\text { marianae }\end{array}$ & 1,2 & McLean (1990) & \\
\hline & & Skeneidae & Ventsia cf. tricarinata & 1,2 & & Fujikura et al. (1997) \\
\hline & & Peltospiridae & $\begin{array}{l}\text { Pachydermia cf. } \\
\text { sculpta }\end{array}$ & 2 & & \\
\hline & & Peltospiridae & Lirapex sp. & 5 & & \\
\hline & & Scissurellidae & Anatoma sp. & 4 & & \\
\hline & & Acmaeidae & Bathyacmaea sp. & 4 & & \\
\hline & & & Protobranchia sp. & 6 & & \\
\hline & & & $\begin{array}{l}\text { Unidentified } \\
\text { gastropod }\end{array}$ & $4,5,6$ & & \\
\hline \multirow[t]{12}{*}{ Arthropoda } & Pycnogonida & Ammotheidae & $\begin{array}{l}\text { Sericosura } \\
\text { cochleifovea }\end{array}$ & 1 & Child (1989) & \\
\hline & Copepoda & Dirivultidae & $\begin{array}{l}\text { Stygiopontius } \\
\text { pectinatus }\end{array}$ & 1 & Humes (1987) & \\
\hline & & Dirivultidae & $\begin{array}{l}\text { Stygiopontius } \\
\text { stabilitus }\end{array}$ & 1 & Humes (1990) & \\
\hline & & Dirivultidae & $\begin{array}{l}\text { Chasmatopontius } \\
\text { thescalus }\end{array}$ & 1 & & \\
\hline & Amphipoda & & $\begin{array}{l}\text { Amphipoda gen. et } \\
\text { sp. }\end{array}$ & 2 & & Fujikura et al. (1997) \\
\hline & Cirripedia & Neoverrucidae & $\begin{array}{l}\text { Neoverruca } \\
\text { brachylepadoformis }\end{array}$ & $\begin{array}{l}1,2,3 \\
4,5\end{array}$ & $\begin{array}{l}\text { Newman and } \\
\text { Hessler (1989) }\end{array}$ & \\
\hline & & & $\begin{array}{l}\text { Scalpellomorpha gen. } \\
\text { et sp. }\end{array}$ & 1 & & $\begin{array}{l}\text { Hessler and Lonsdale (1991), } \\
\text { photograph only }\end{array}$ \\
\hline & Decapoda & Galatheidae & $\begin{array}{l}\text { Munidopsis } \\
\text { marianica }\end{array}$ & 1,2 & $\begin{array}{l}\text { Williams and Baba } \\
\text { (1989) }\end{array}$ & \\
\hline & & Galatheidae & Munidopsis sp. & $3,5,6$ & & \\
\hline & & Bythogreidae & $\begin{array}{l}\text { Austinograea } \\
\text { williamsi }\end{array}$ & $\begin{array}{l}1,2,3 \\
4,5,6\end{array}$ & $\begin{array}{l}\text { Hessler and Martin } \\
\text { (1989) }\end{array}$ & \\
\hline & & Alvinocarididae & $\begin{array}{l}\text { Chorocaris } \\
\text { vandoverae }\end{array}$ & $\begin{array}{l}1,2,3 \\
4,5,6\end{array}$ & $\begin{array}{l}\text { Martin and Hessler } \\
\text { (1990) }\end{array}$ & \\
\hline & & Alvinocarididae & Chorocaris sp. & $3,5,6$ & & \\
\hline
\end{tabular}

${ }^{a}$ 1, Alice Springs site; 2, Forecast site; 3, Snail site; 4, Archaean site; 5, Pika site; 6, Urashima site; 7, Yamanaka site

between two sites (3,600 vs. 1,470 m), they reported that the faunas are quite similar to each other (Fujikura et al. 1997).

During 2000s, vent fields in the southernmost region of the Mariana Trough were surveyed in the second stage of the Archaean project (2003-2004) and the NOAA VENTS program. As few macrobiologists joined these projects, little information on their vent faunas was available. Wheat et al. (2003) reported they sampled a provannid snail Alviniconcha hessleri and crabs from the Snail site. An abundant anemone colony was observed in the southern part of the Yamanaka site (Kakegawa et al. 2008).

As an activity of the TAIGA Project, we collected biological specimens at four vent sites in the southernmost region of the Mariana Trough, namely, the Snail, Archaean,
Pika, and Urashima sites, during the cruise YK10-11 of the $\mathrm{R} / \mathrm{V}$ YOKOSUKA and the submersible SHINKAI 6500 of Japan Agency for Marine-Earth Science and Technology (JAMSTEC). Results obtained from the sampling are also shown in Chap. 26.

At the Snail site, the largest animal community was observed around the chimney with fringe structure. The center of the community was dominated by $A$. hessleri assemblage and accompanied with Shinkailepas limpets, Austinograea crabs, and Chorocaris shrimps. Further apart from the chimney, only a few shrimp and crab were observed. The outermost part of the vent field was occupied by the turrid snail Phymorhynchus sp., two kinds of sea anemones, and ophidiiformes. At the Archaean site, only 
small and scattered animal communities were observed. On the steep terrain of the mound, galatheid crabs, brisingids, actinostolid-like anemones, and Abyssocladia sponges were observed. Around active chimneys, Shinkailepas limpets were abundant and attached to the vertical surface. Alviniconcha hessleri inhabits the narrow place coved with white bacterial mat. We observed a wide size range of galatheids and small bythograeids, actinostolid-like anemones in diffuse flow, and shrimp and crabs were abundant in the shimmering flow of the vent itself. Two large bivalves were found in a crevice at the base of the chimney but could not be collected. Chorocaris shrimps and Austinograea crabs were also common. On the steep slope of the Pika mound, a few white bythograeid crabs are distributed and many empty shells of Alviniconcha seemed to have fallen from above. With approaching to the summit, Phymorhynchus snails, galatheid and bythograeid crabs, and Desbruyeresia gastropods appeared although the fauna was very sparse there. We noticed a small population of $A$. hessleri on the side of a chimney. Shrimps were swimming around them. There were also scattered limpets. At the Urashima site, vent fauna was not so abundant, although shrimps, galatheid crabs, anemones and a few small gastropods were distributed in a place with strong diffuse flow. In total 19 species were observed and collected in these four hydrothermal vent sites. Although the most flourishing fauna was observed at the Snail site on-axis, the number of species was highest at off-axis Pika and Archaean sites. During this cruise, the sampling of larvae of vent animals was carried out around vent fields using plankton pump systems for the first time in the southernmost region of the Marana Trough and 13 and 15 morphotypes of polychaete and gastropod larvae were sampled, respectively (Beaulieu et al. 2011; Sasaki et al. unpublished data).

We also revisited the Yamanaka site where abundant white sea anemones were observed on pillow lavas. This site was thought to have passed its peak of hydrothermal activity (Yoshikawa et al. 2012).

Unfortunately, no detailed faunal information is available for the $13^{\circ} \mathrm{N}$ Ridge site with the exception of observation of animals around hydrothermal vents by the Deep Tow Camera system and the ROV KAIKO (Mitsuzawa et al. 2000; Masuda et al. 2001b).

\subsubsection{Mollusca}

The most dominant species of the communities in hydrothermal vent fields in the Mariana Trough is a large provannid gastropod Alviniconcha hessleri (Okutani and Ohta 1988). To date, this species is known only from the Mariana Trough, and Alvinoconcha gastropods inhabiting the Manus, North Fiji, and Lau Basins, and the Indian Ocean are thought to be other undescribed species (Kojima et al. 2001; Suzuki et al. 2006). Although no genetic differentiations between the Alice Springs and the Forecast Vent site were detected for this species (Kojima et al. 2001), our more detailed analysis showed a slight difference between populations of the Central and Southern Mariana Trough (Hidaka et al. Chap. 26). By using the DNA barcoding, two larvae of this species were identified in the specimens collected by plankton pump systems mentioned above (Sasaki et al. unpublished data). Based on shell morphology, they are judged to be planktotrophic as Warèn and Bouchet (1993) concluded based on young adult specimens of an undescribed Alviniconcha species from the Lau Basin. Sulfur-oxidizing endosymbiotic bacteria were discovered in specialized gill cells (bacteriocytes) of $A$. hessleri (Stein et al. 1988; Endow and Ohta 1989). They belong to the gammaproteobacteria, although some undescribed Alvinoconcha species endosymbiose with epsilonproteobacteria (Suzuki et al. 2005, 2006). Wittenberg and Stein (1995) reported that the gill of $A$. hessleri contents hemoglobin at a comparable concentration to endosymbiontretaining solemyid, lucinid, and vesicomyid clams. Sulfur stable isotope ratios of $A$. hessleri showed sulfide in hydrothermal fluid is the major source of assimilated sulfur, which is supplied by endosymbiotic bacteria (Maki and Mizota 1997).

Two small provannid gastropod species were described by Okutani (1990). They are classified into the genus Provanna as $P$. nassariaeformis and $P$. marianensis, and the latter was transferred to the genus Desbryuesia in Warèn and Bouchet (1993).

Vrijenhoek et al. (1997) showed that a limpet of the genus Lepetodrilus from the Mariana Trough, which had been thought to be conspecific to that in the Eastern Pacific, is genetically distinct from East Pacific species. Johnson et al. (2008) analyzed phylogenetic relationships among Lepetodrilus limpets and showed those of the Mariana Trough form a species complex with L. schrolli from the Manus Basin and unidentified individuals from the North Fiji and Lau Basins. Limpets of the genus Shinkailepas also dominate vent fields in the Mariana Trough as well as the Izu-Ogasawara Arc. Although Shinkailepas limpets of the Mariana Trough resemble to S. kaikatensis of which the type locality is the Kaikata Seamount in the Izu-Ogasawara Arc and were referred as Shinkailepas cf. kaikatensis in Hessler and Lonsdale (1991) and Fujikura et al. (1997), DNA barcoding and detailed morphological examination clearly showed those of the Mariana Trough are not $S$. kaikatensis which was described based on specimens from the Izu-Ogasawara Arc (Kano et al., unpublished data).

Genetic analysis with mitochondrial DNA also showed little genetic deviation among morphologically-distinct 
species, namely, Bathymodiolus septemdierum from the Izu-Ogasawara Arc, Bathymodiolus sp. from the Mariana Trough, B. brevior from the North Fiji and Lau Basins, and B. marisindicus from the Indian Ocean (Fujita et al. 2009). If they are a single species with extremely high ability of larval dispersion, the situation is very similar to that of a vestimentiferan Paraescarpia echinospica, which are distributed from the Nankai Trough in the northwestern Pacific to the Java Trench in the Indian Ocean but not in the Mariana Trough (Kojima et al. 2002).

\subsubsection{Arthropoda}

A bythograeid crab, Austinograea williamsi, which was described by Hessler and Martin (1989) is also a representative vent-endemic species in the Mariana Trough. Its heterochely, relative growth and gonad morphology were reported in Tsuchida and Fujikura (2000).

To date, all alvinocarid shrimps collected in the Mariana Trough have been classified into the genus Chorocaris. Besides a dominant alvinocarid shrimp Chorocaris vandoverae, we collected some specimens of an undescribed Chorocaris shrimp at the Snail, Pika, and Urashima sites. Based on sulfur stable isotope ratio analysis, Maki and Mizota (1997) reported that $C$. vandoverae is supplied sulfur from hydrogen sulfide in hydrothermal fluid.

A hydrothermal vent-endemic barnacle Neoverruca brachylepadoformis is closely related to an undescribed species inhabiting the Okinawa Trough, Izu-Ogasawara Arc, and the Mariana Arc. Their ancestors were estimated to have migrated from the Mariana Trough to the IzuOgasawara Arc and the Mariana Arc via the Okinawa Trough based on the molecular phylogenetic and phylogeoraphic analyses (Watanabe and Kojima 2009; Watanabe et al. 2005).

\subsubsection{Annelida}

Paralvinella hessleri is one of the dominant annelid species. This species is also thought to inhabit the Okinawa Trough and the Izu-Ogasawara Arc. A molecular phylogenetic analysis using the mitochondrial COI gene showed that populations of the Okinawa Trough and the Izu-Ogasawara Arc are almost deviated from each other (Pradillon et al., unpublished data). As no molecular data is available for the Mariana Trough population and we cannot deny the possibility that Paralvinella annelids of the Okinawa Trough and the Izu-Ogasawara Arc are another cryptic species of $P$. hessleri.

\subsection{Vent/Seep Faunas of Neighboring Sea Areas}

\subsubsection{Mariana Arc, Izu-Ogasawara Arc, and Okinawa Trough}

The Mariana Trough approaches to the Mariana Arc at both northern and southern ends (Fig. 25.1). Along the Mariana Arc, hydrothermal activities were discovered on 13 submarine volcanoes at the depths from 50 to $3,000 \mathrm{~m}$, and chemosynthetic-based communities was reported from the Nikko, Daini (second) Kasuga, NW Eifuku, Daifuku, and NW Rota-1 Seamounts and TOTO Caldera (Fujikura et al. 1998; Masuda et al. 2001a; Embley et al. 2007). At the northern end, the Mariana Arc connects with the Izu-Ogasawara Arc. Although the Mariana Trough also adjoins the Mariana Arc at the northern end, the recent hydrothermalism has not yet been discovered in the northern region of the Mariana Trough. Indeed, the vent fauna of the Mariana Trough is rather similar to that of the Okinawa Trough (Fig. 25.2). As planktonic materials can be transported by the North Equatorial Current and the Kuroshio Current from the Mariana Trough to the Okinawa Trough, historical larval migration might have occurred along this route (Watanabe et al. 2005).

An Alviniconcha snail, which is a representative ventendemic taxon of the Mariana Trough, has not been reported north of the Mariana Trough with the exception of a single specimen collected from the Suiyo Seamount, the IzuOgasawara Arc. It phylogenetically differs from A. hessleri and all other Alviniconcha lineages (Fujiwara et al. 2013) and is suspected to have immigrated to this vent field accidentally. Habitat(s) of this undescribed species may be situated in other vent fields in the Izu-Ogasawara and/or Mariana Arcs. Although small gastropods of the genera Provanna, Desbruyeresia, Lepetodrilus and Shinkailepas inhabit vent fields in both the Mariana Trough and neighboring sea areas, the existence of endemic species to the Mariana Trough was shown for each genus. Vesicomyid clams were collected in the TOTO Caldera and identified as Calyptogena nautilei (Kojima et al., unpublished data).

Alvinocaris shrimps have not yet been reported from the Mariana Trough while an undescribed species of this genus was discovered in two vent fields of the Mariana Arc, namely, NW Rota (Limén et al. 2006) and NW Eifuku, which will be described as a new species (Tsuchida, personal communication). Four Alvinocaris shrimps, namely, A. longirostris, A. dissimilis, A. brevitelsonis, and an undescribed species inhabit the Okimawa Trough (Komai and Segonzac 2005; Fujikura et al. 2012; Yahagi et al., unpublished data). This undescribed species was also 


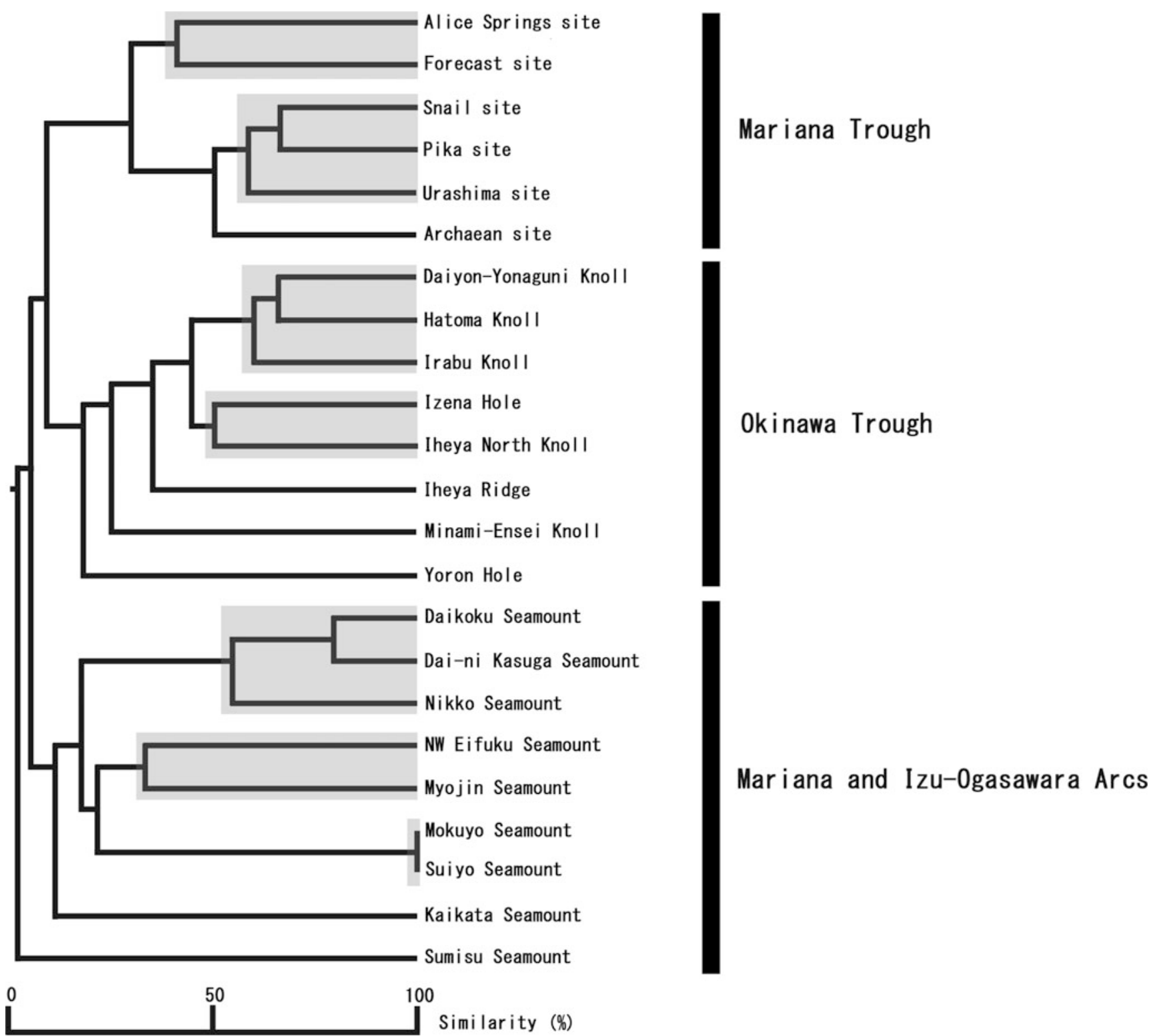

Fig. 25.2 A cladogram of hydrothermal vent faunas in the Mariana Trough, Mariana Arc, Izu-Ogasawara Arc, and Okinawa Trough, generated by the group average method using the Jaccard similarity coefficient based on genera. Data of Table 25.1 were used for the Mariana Trough, data of the Mariana Arc, Izu-Ogasawara Arc, and

collected from the Suiyo Seamount in the Izu-Ogasawara Arc (Yahagi et al., unpublished data). Austinograea williamsi is an endemic species to the Mariana Trough and differs from bythograeid crabs from the Izu-Ogasawara and Mariana Arcs at the genus level. Munidopsis marianica is also endemic to the Mariana Trough while some congeneric species inhabit vent fields in the Mariana Arc, IzuOgasawara Arc, and/or Okinawa Trough. For Neoverruca barnacles, significant genetic differences were shown among specimens from the Mariana Trough, the Okinwa Trough, and the Izu-Ogawsawara Arc (Watanabe 2004). Individuals
Okinawa Trough were updated from those in Watanabe et al. (2010), and only data of identified genera were used. Among faunas in gray areas, no significant difference $(p>0.05)$ was detected by the SIMPROF (similarity profile) test with 1,000 permutations

of the Izu-Ogasawara Arc were further shown to form a monophyletic group with those from the Mariana Arc (Watanabe et al., unpublished data).

Vestimentiferan tube worms, which form one of representative groups of hydrothermal vent fields in the Okinawa Trough and the Manus Basin, has not yet been reported from the Mariana Trough. They are also rare in the Mariana Arc where two species are found; Lamellibrachia satsuma from the Nikko and Daikoku Seamounts (Black et al. 1997; Kojima et al. 2012) and L. juni from the TOTO Caldera (Kojima et al. 2006). The former is known from the seep 
area around the Japanese Islands at shallower depths than $330 \mathrm{~m}$. The absence of this species in the Mariana Trough might be attributable to the absence of such a shallow vent site. The latter is also known from the DESMOS site in the Manus Basin and the Brothers Caldera in the Kermadec Arc (Kojima et al. 2006). All of three habits of this species are characterized by extreme acidic hydrothermal fluids (around $\mathrm{pH}$ 2). If this species has been specialized to such a harsh environment, it may explain its absence in the Mariana Trough.

While symphurine tonguefish are distributed in the Mariana Arc, the Izu-Ogasawara Arc, and the Okinawa Trough, they have not been reported from the Mariana Trough. Tunnicliffe et al. (2010) reported that a symphurine tonguefish Symphurus thermophilus inhabiting vent fields at the Daikoku, Nikko, and Daini (second) Kasuga Seamounts is genetically distinct from those of the Kermadic arc in spite of no morphological difference between them and suggested the possibility that the latter is a cryptic species. The type locality of $S$. thermophilus is the Kaikata Samount of the Izu-Ogasawara Arc (Munroe and Hashimoto 2008) and individuals in the Mariana Arc might be classified into another cryptic species. Unfortunately, no molecular information is available for symphurines of the Izu-Ogasawara Arc and the Okinawa Trough.

\subsubsection{Mariana Forearc and Mariana Trench}

Many serpentinite mud volcanoes are known in the Mariana forearc between the Mariana volcanic island arc and the Mariana Trench. In 1997, a methane seep area with a highly alkaline fluid was discovered on one of those mud volcanoes, the South Chamorro Seamount (Fryer and Mottl 1997). Bathymodiolus mussels inhabiting this field were shown to be genetically distinct from those of the Mariana Trough (Fujita et al. 2009). Vesicomyid clams collected in this area were identified as Calyptogena nautilei (Kojima et al., unpublished data). Although Fryer and Mottl (1997) also reported "tube worms" from this site, their detailed information is not available.

A distinct chemosynthesis-based community was recently discovered in a methane seep area (Shinkai Seep Field) on the landward slope of the Mariana Trench (Ohara et al. 2012). From there, a new species of vesicomyid clams Calyptogena mariana was described (Okutani et al. 2013). This species was classified into the subgenus Abyssogena and shown to be more related to species of the abyssal depths such as $C$. kaikoi from seep areas in the Nankai Trough off the Japanese mainland than inhabitants of the Mariana Arc. To date, no species of the Mariana Trough have been reported from methane seep areas around Japan.

\subsubsection{Backarc Basins in the South Pacific}

Hydrothermal vent fields in backarc basins in the South Pacific, namely, the Manus Basin, the North Fiji Basin, and the Lau Basin, share Alviniconcha snails as a dominant species with the Mariana Trough. Those of the South Pacific were estimated to have speciated into two different undescribed species. Ifremeria nautilei is also a large snail with endosymbiotic chemoautotrophic bacteria. Although this species forms a monophyletic group with Alviniconcha snails, it is not distributed in the Mariana Trough. Chemosynthesis-based communities of the Mariana Basin lack vestimentiferan annelids and Calyptogena clams, while the former is distributed in the Manus Basin and the Lau Basin (Desbruyères et al. 2006) and the later is distributed at a single site (the DESMOS caldera) in the Manus Basin (Hashimoto et al. 1999). Bythograeid crabs of the genus Austinograea are known from the Mariana Trough (A. williamsi), the South Pacific (A. alayseae), and the Indian Ocean (A. rodriguezensis).

\subsection{Conclusion}

Diversity of hydrothermal environments and vent faunas in the western Pacific is probably due to their various backgrounds and two-dimensional distribution, which results in complicated connectivity between vent sites, in addition to proximity of vent areas with different geological settings as well as cold seep areas. In contrast, hydrothermal vent fields in the eastern Pacific, Atlantic and Indian Oceans are distributed along the mid-oceanic ridges and essentially aligned. Thus, the western Pacific is expected to offer interesting subjects for researches of dispersal, genetic deviation, and speciation processes of animals endemic to chemosynthesis-based communities. Comparative studies between the western Pacific and other sea areas are important for understanding evolution and ecology of vent fauna.

The Mariana Trough is situated in the central position in hydrothermal areas in the northwestern Pacific, surrounded by the Okinawa Trough, the Izu-Ogasawara Arc, the Mariana Arc, and the Manus Basin. Chemosynthesis-based communities in the Mariana Trough are characterized by the absence of vestimentiferans and Calyptogena clams, which are dominant in both vent and seep sites around the Ryuykyu and Japan Islands, the dominance of Alviniconcha snails and Austinograea crabs, which is shared with the South Pacific and the Indian Ocean. Phylogeographic analyses showed Neoverruca barnacles have historically migrated from the Mariana Trough to the Izu-Ogasawara Arc and the Mariana Arc via the Okinawa Trough (Watanabe and Kojima 2009; Watanabe et al. 2005). They were further estimated to have deviated from a common ancestor species which inhabited 
the Manus Basin (Watanabe 2004), which suggest the primary historical migration in the western Pacific occurred in the northward direction. Similar suggestions have been noted for Alviniconcha snails (Kojima et al. 1999) and Alaysia-like vestimentiferans (Kojima et al. 2003).

A very interesting issue is a biogeographic break of the vent fauna between the Mariana Trough and the IzuOgasawara and Mariana Arcs. It may be attributable to directions of surface currents, namely, the North Equatorial Current and the Kuroshio Current, and/or the absence of active vent sites in the northernmost region of the Mariana Trough where the trough is adjacent to the arcs. In the southernmost region, extreme acidic hydrothermal fluids of the TOTO Caldera might prevent the vent fauna of the Mariana Trough from colonizing to the arc area.

The Mariana Trough is a key place connecting various vent and seep sites in the western Pacific. Exhaustive survey in this area with joint research using phylogeographic and larval ecological methodologies will provide fruitful results for understanding organization mechanisms of vent communities.

Acknowledgements The authors are grateful to the operation teams of the submersible SHINKAI 6500, the crew of the support ship Yokosuka, and onboard scientists of the YK10-11 cruise of Yokosuka for help in sampling. We also thank Drs. Takashi Okutani, Jun Hashimoto, Shinji Tsuchida, Yasunori Kano, and Takuya Yahagi for taxonomic information. Thanks are also extended to two reviewers for comments that improved manuscript. This study was conducted as an activity of the scientific research on innovative areas "TAIGA (Trans-crustal Advection \& In situ bio-geochemical processes of Global sub-seafloor Aquifer)" which is sponsored by Ministry of Education, Culture, Sports, Science and Technology (MEXT), Japan (No. 20109004). We also referred to results by KAKENHI (No. 23370040).

Open Access This chapter is distributed under the terms of the Creative Commons Attribution Noncommercial License, which permits any noncommercial use, distribution, and reproduction in any medium, provided the original author(s) and source are credited.

\section{References}

Beaulieu SE, Mills S, Mullineaux L, Pradillon F, Watanabe H, Kojima S (2011) International study of larval dispersal and population connectivity at hydrothermal vents in the southern Marianas Trough. InterRidge News 20:50-54

Black MB, Halanych KM, Mass PAY, Hoeh WR, Hashimoto J, Desbruyères D, Lutz RA, Vrijenhoek RC (1997) Molecular systematics of vestimentiferan tubeworms from hydrothermal vents and cold-water seeps. Mar Biol 130:141-149

Blake JA (1991) A new species of Hesiocaeca (Polychaeta: Hesionidae) from hydrothermal vents at the Mariana Back-Arc Basin with notes on other polychaetes. Proc Biol Soc Wash 104:175-180

Child CA (1989) Pycnogonida of the western Pacific islands VI. Sericocura cochleifovea, a new hydrothermal vent species from the Mariana Back-Arc basin. Proc Biol Soc Wash 102:732-737
Craig H, Horibe Y, Farley KA, Welhan JA, Kim K, Hey RN (1987) Hydrothermal vents in the Mariana Trough: results of the first Alvin dives. Eos Trans AGU 68:1531

Desbruyères D, Laubier L (1989) Paralvinella hessleri, new species of Alvinellidae (Polychaeta) from the Mariana Bach-Arc Basin hydrothermal vents. Proc Biol Soc Wash 102:761-767

Desbruyères D, Hashimoto J, Fabri M-C (2006) Composition and biogeography of hydrothermal vent communities in western Pacific back-arc basins. In: Christie DM, Fisher CR, Lee S-M, Givens S (eds) Back-arc spreading systems: geological, biological, chemical, and physical interactions. The American Geophysical Union, Washington, DC, pp 215-234

Embley RW, Baker ET, Butterfield DA, Chadwick WW Jr, Lupton JE, Resing JA, De Ronde CDJ, Nakamura K, Tunnicliffe V, Dower JF, Merle SG (2007) Exploring the submarine ring of fire: Mriana Arc Western Pacific. Oceanography 4:68-79

Endow K, Ohta S (1989) The symbiotic relationship between bacteria and a mesogastropod snail, Alviniconcha hessleri, collected from hydrothermal vents of the Mariana Back-Arc Basin. Bull Jap Soc Microbial Ecol 3:73-82

Fautin DG, Hessler RR (1989) Marianactis bythios, a new genus and species of actinostolid sea anemone (Coelenterata: Actiniaria) from the Mariana vents. Proc Biol Soc Wash 102:761-767

Fryer P, Mottl MJ (1997) "Shinkai 6500" investigations of a resurgent mud volcano on the southern Mariana forearc. JAMSTEC J Deep Sea Res 13:103-114

Fujikura K, Yamazaki T, Hasegawa K, Tsunogai U, Stein RJ, Ueno H, Yamamoto H, Maki Y, Tsuchida S, Kodera T, Yamamoto H, Sun C, Okutani T (1997) Biology and earth scientific investigation by the submersible "Shinkai 2000" system of deep-sea hydrothermalism and lithosphore in the Mariana Back-Arc Basin. JAMSTEC J Deep Sea Res 13:1-20 (in Japanese with English abstract)

Fujikura K, Tsuchida S, Ueno H, Ishibashi J, Gaze W, Maki Y (1998) Investigation of the deep-sea chemosynthetic ecosystem and submarine volcano at the Kaguga 2 and 3 Seamounts in the Northern Mariana Trough, Western Pacific. JAMSTEC J Deep Sea Res 14:127-138

Fujikura K, Okutani T, Maruyama T (eds) (2012) Deep-sea life; biological observations using research submersibles, 2nd edn. Tokai University Press, Kanagaawa (in Japanese with English figure captions)

Fujita Y, Matsumoto H, Fujiwara Y, Hashimoto J, Galkin SV, Ueshima R, Miyazaki J (2009) Phylogenetic relationships of deep-sea Bathymodiolus mussels to their mytilid relatives from sunken whale carcasses and wood. Venus 67:123-134

Fujiwara Y, Okutani T, Kimura H (2013) First occurrence of Alviniconcha from Japanese waters (Gastropoda: Provannidae). Venus 71:217-219

Hasegawa K, Fujikura K, Okutani T (1997) Gastropod fauna associated with hydrothermal vents in the Mariana Back-Arc Basin: summary of the results of 1996 "Shinkai 6500" dives. JAMSTEC J Deep Sea Res 13:69-83

Hashimoto J, Ohta S, Fiala-Médione A, Auzende J-M, Kojima S, Segonzac M, Fujiwara Y, Hunt JC, Gena K, Miura T, Kikuchi T, Yamaguchi T, Toda T, Chiba H, Tsuchida S, Ishibashi J, Henry K, Zbinden M, Pruski A, Inoue A, Kobayashi H, Birrien J-L, Naka J, Yamanaka T, Laporte C, Nishimura K, Yeats C, Malagun S, Kia P, Oyaizu M, Katayama T (1999) Hydrothermal vent communities in the Manus Basin, Papua New Guinea: results of the BIOACCESS cruises'96 and'98. InterRidge News 8(2):12-18

Hessler RR, Lonsdale PF (1991) Biogeography of Mariana Trough hydrothermal vent communities. Deep-Sea Res 38:185-199

Hessler RR, Martin WM (1989) Austinograea williamsi, new genus, new species, a hydrothermal vent crab (Decapoda: Bythograeidae) from the Mariana Back-Arc Basin, western Pacific. J Crust Biol 9:645-661 
Humes AG (1987) Copepoda from deep-sea hydrothermal vents. Bull Mar Sci 41:645-788

Humes AG (1990) Copepoda (Siphonostomatoida) from a deep-sea hydrothermal vent at the Mariana Back-Arc Basin in the Pacific, including a new genus and species. J Nat Hist 24:289-304

Ishibashi J, Yamanaka T, Kimura H, Hirota A, Toki T, Tsunogai U, Gamo T, Utsumi M, Roe K, Miyabe S, Okamura K (2004) Geochemistry of hydrothermal fluids in South Mariana backarc spreading center. EOS Trans AGU 85, Fall Meet Suppl, F1908

Johnson L, Fryer H, Matsuda H, Ishii T, Gamo T (1993) Hydrothermal deposits and two magma sources for volcanoes near $13^{\circ} 20^{\prime} \mathrm{N}$ in the Mariana backarc: a view from Shinkai 6500. EOS Trans AGU 74, Fall Meet Suppl, p 381

Johnson SB, Warén A, Vrijenhoek RC (2008) DNA barcoding of Lepetdrilus limpets reveals cryptic species. J Shellfish Res 27:43-51

Kakegawa T, Utsumi M, Marumo K (2008) Geochemistry of sulfide chimneys and basement pillow lavas at the southern Mariana Trough $\left(12.55^{\circ} \mathrm{N}-12.58^{\circ} \mathrm{N}\right)$. Res Geol 58:249-266

Kojima S, Ohta S, Fujiwara Y, Fujikura K, Hashimoto J (1999) Speciation of gastropods of the genus Alviniconcha in the South Pacific. JAMSTEC J Deep Sea Res 14:501-505 (in Japanese with English abstract)

Kojima S, Segawa R, Fujiwara Y, Fujikura K, Ohta S, Hashimoto J (2001) Phylogeny of hydrothermal vent-endemic gastropods Alviniconcha spp. from the Western Pacific revealed by mitochondrial DNA sequences. Biol Bull 200:298-304

Kojima S, Ohta S, Yamamoto T, Miura T, Fujiwara Y, Fujikura K, Hashimoto J (2002) Molecular taxonomy of vestimentiferans of the Western Pacific and their phylogenetic relationship to species of the Eastern Pacific. II. Families Escarpiidae and Arcovestiidae. Mar Biol 141:57-64

Kojima S, Ohta S, Yamamoto T, Yamaguchi T, Miura T, Fujiwara Y, Fujikura K, Hashimoto J (2003) Molecular taxonomy of vestimentiferans of the Western Pacific and their phylogenetic relationship to species of the Eastern Pacific. III. Families Alaysia-like vestimentiferans and relationships among families. Mar Biol 142:625-635

Kojima S, Watanabe H, Tsuchida S, Fujikura K, Rowden AA, Takai K, Miura T (2006) Phylogenetic relationships of a tube worm (Lamellibrachia juni) from three hydrothermal vent fields in the South Pacific. J Mar Biol Assoc UK 86:1357-1361

Kojima S, Murakami S, Nemoto S, Watanabe H, Miyake H, Tsuchida S (2012) Genetic diversity and population structure of a vestimentiferan annelid Lamellibrachia satsuma in Japanese and northern Mariana waters. Plankton Benthos Res 7:146-150

Komai T, Segonzac M (2005) A revision of the genus Alvinocaris Williams and Chase (Crustacea: Decapoda: Caridea: Alvinocarididae), with descriptions of a new genus and a new species of Alvinocaris. J Nat History 39:1111-1175

Limén H, Juniper SK, Tunnicliffe V, Clément M (2006) Benthic communities on two peaks of an erupting seamount: Northwest Rota-1 Volcano, Mariana Arc, western Pacific. Cah Biol Mar 47:457-463

Maki Y, Mizota C (1997) Sulfur isotopic comparison of Alviniconcha hessleri and Chorocaris vandoverae from Mariana Back-Arc Basin. JAMSTEC J Deep Sea Res 13:63-67 (in Japanese with English abstract)

Martin JW, Hessler RR (1990) Chorocaris vandoverae, a new genus and species of hydrothermal vent shrimp (Crustacea, Decapoda, Bresiliidae) from the western Pacific. Contr Sci Nat His Mus Los Angeles Country 417:1-11

Masuda H, Mitsuzawa K, Seama N, Masumoto S, YK-99-11 Shipboard Scientific Party (2001a) Bathymetry and hydrothermal activities in the southern Mariana Trough - reconnaissance results of YK-99-11. JAMSTEC J Deep Sea Res 18:83-88 (In Japanese with English abstract)
Masuda H, Nakagawa S, The Shipboard Scientific Party of KK-00-03 (2001b) Newly found low temperature hydrothermal activities at the southern Mariana back arc basin - summary of Dive \#164 during KK-00-03. JAMSTEC J Deep Sea Res 18:89-93 (In Japanese with English abstract)

McLean JH (1990) A new genus and species of neomphalid limpet from the Mariana vents, with a review of current understanding of relationships among Neomphalacea and Peltospiracea. The Nautilus 104:77-86

Mitsuzawa K, Matsuda H, Seama N, Hasegawa Y, Miyamoto M, Togashi N, So A, Yamanobe H (2000) Preliminary report of Deep-Tow/Yokosuka Cruise at hydrothermal areas in the Mid and Southern Mariana. JAMSTEC J Deep Sea Res 17:73-87 (in Japanese with English abstract)

Munroe TA, Hashimoto J (2008) A new Western Pacific Tonguefish (Pleuronectiformes: Cynoglossidae): the first Pleuronectiform discovered at active hydrothermal vents. Zootaxa 1839:43-59

Nakamura K, Toki T, Mochizuki N, Asada M, Ishibashi J, Nogi Y, Yoshikawa S, Miyazaki J, Okino K (2012) Discovery of a new hydrothermal vent based on an underwater, high-resolution geophysical survey. Deep Sea Res I 74:1-10

Newman WA, Hessler RR (1989) A new abyssal hydrothermal verrucomorphan (Cirripedia; Sessilia): the most primitive living sessile barnacle. Trans San Diego Soc Nat Hist 21:259-73

Ohara Y, Reagan M, Fujikura K, Watanabe H, Michibayashi K, Ishii T, Stern R, Pujana I, Martinez F, Girard G, Ribeiro J, Brounce M, Komori N, Kino M (2012) A serpentinite-hosted ecosystem in the southern Mariana Forearc. Proc Natl Acad Sci USA 109:2831-2835

Okutani T (1990) Two new species of Provanna (Gastropoda: Cerithiacea) from "snail pit" in the hydrothermal vent site at the Mariana Back-Arc Basin. Venus (Jpn J Malac) 59:83-101

Okutani T, Ohta S (1988) A new gastropod mullusk associated with hydrothermal vents in the Mariana Back-Arc Basin, Western Pacific. Venus (Jpn J Malac) 47:211-218

Okutani T, Fujikura K, Watanabe H, Ohara Y (2013) Calyptogena (Abyssogena) mariana: Discovery of a new vesicomyid clam from the Mariana Trench. Venus 71:39-47

Pettibone MH (1989) New species of scale-worms (Polychaeta: Polynoidae) from the hydrothermal rift-area of the Mariana BackArc Basin in the western central Pacific. Proc Biol Soc Wash 102:137-153

Stein JL, Cary SC, Hessler RR, Ohta S, Vetter RD, Childress JJ, Felbeck H (1988) Chemoautotrophic symbiosis in a hydrothermal vent gastropod. Biol Bull 174:373-378

Stern RJ, Fouch MJ, Klemperer SL (2003) An overview of the IzuBonin-Mariana subduction factory. In: Eiler J, Hirschmann M (eds) Inside the subduction factory. American Geological Union, Washington, DC, pp 175-222

Stern RJ, Tamura Y, Masda H, Fryer P, Martinez F, Ishizuka O, Bloomer SH (2013) How the Mariana volcanic arc ends in the south. Island Arc 22:133-148

Stüben D, Taibi NE, McMurtry GM, Scholten J, Stoffers P, Zhang D (1994) Growth history of a hydrothermal silica chimney from the Mariana backarc spreading center (southwest Pacific, $18^{\circ} 21^{\prime} \mathrm{N}$ ). Chem Geol 113:273-296

Suzuki Y, Sasaki T, Suzuki M, Nealson KH, Horikoshi K (2005) Molecular phylogenetic and isotopic evidence of two lineages of chemoautotrophic endosymbionts distinct at the subdivision level harbored in the one host-animal type: the genus Alviniconcha (Gastropoda: Provannidae). FEMS Microbiol Lett 249:105-112

Suzuki Y, Kojima S, Sasaki T, Suzuki M, Utsumi T, Watanabe H, Urakawa H, Tsuchida S, Nunoura T, Hirayama H, Takai K, Nealson KH, Horikoshi K (2006) Host-symbiont relationships in hydrothermal vent gastropods of the genus Alviniconcha from the South West Pacific. Appl Environ Microbiol 72:1388-1393 
Takamasa A, Nakai S, Sato F, Toyoda S, Banerjee D, Ishibashi J (2013) U-Th radioactive disequilibrium and ESR dating of a barite-containing sulfide crust from South Mariana Trough. Quat Geochronol 15:38-46

Tsuchida S, Fujikura K (2000) Heterochely, relative growth, and gonopod morphology in the bythograeid crab, Austinograea williamsi (Decapoda, Brachyura). J Crust Res 20:407-414

Tunnicliffe V, Koop BF, Tylerand J, So S (2010) Flatfish at seamount hydrothermal vents show strong genetic divergence between volcanic arcs. Mar Ecol 31(Suppl 1):158-167

Urabe T, Ishibashi J, Maruyama A, Marumo K, Seama N, Utsumi M (2004) Discovery and drilling of on- and off-axis hydrothermal sites in backarc spreading center of southern Mariana Trough, western Pacific. EOS Trans AGU 85, Fall Meet Suppl, F1907

Vrijenhoek RC, Feldman RA, Lutz RA, Craddock C, Hashimoto J (1997) Genetic characterization of Lepetodrilus limpets from hydrothermal vents in the Mariana Trough. JAMSTEC J Deep Sea Res (special volume "Deep sea research in subduction zones, spreading centers and backarc basins) pp 111-116

Warèn A, Bouchet $\mathrm{P}$ (1993) New records, species, genera, and a new family of gastropods from hydrothermal vents and hydrocarbon seeps. Zool Scr 22:1-90

Watanabe H (2004) Larval ecology and genetic differentiation of hydrothermal vent-endemic barnacles of the family neoverrucidae. PhD. thesis, Dep. of Biol. Sci., Univ. of Tokyo, Tokyo, Japan

Watanabe H, Kojima S (2009) Dispersal and speciation of faunal groups endemic to hydrothermal vent fields. In: Nishida $M$ (ed) Evolution in the sea: molecular phylogenetic approaches to the marine diversity. Tokai University Press, Kanagawa, pp 244-260 (in Japanese)

Watanabe H, Tsuchida S, Fujikura K, Yamamoto H, Inagaki F, Kyo M, Kojima S (2005) Population history associated with hydrothermal vent activity inferred from the genetic structure of neoverrucid barnacles around Japan. Mar Ecol Prog Ser 288:233-240

Watanabe H, Fujikura K, Kojima S, Miyazaki J, Fujiwara Y (2010) Vents and seeps in close proximity. In: Kiel S (ed) The vent and seep biota, Topics in geobiology, vol 33. Springer, Dordrecht, pp 379-401

Wheat CG, Fryer P, Hulme SM, Becker NC, Curtis A, Moyer C (2003) Hydrothermal venting in the southern most portion of the Mariana backarc spreading center at 12.57 degrees N. EOS Trans AGU 84, Fall Meet Suppl, F1399

Williams AB, Baba K (1989) New squat lobsters (Galatheidae) from the Pacific Ocean: Mariana Back Arc Basin, East Pacific Rise, and Cascadia Basin. Fish Bull 87:899-910

Wittenberg JB, Stein JL (1995) Hemoglobin in the symbiont harboring gill of the marine gastropod Alviniconcha hessleri. Biol Bull 188:5-7

Yoshikawa S, Okino K, Asada M (2012) Geomorphological variations at hydrothermal sites in the southern Mariana Trough: relationship between hydrothermal activity and topographic characteristics. Mar Geol 303-306:172-182

Zottoli R (1983) Amphisamytha galapogensis, a new species of ampharetid polychaete from the vicinity of abyssal hydrothermal vents in the Galápagos Rift, and the role of this species in rift ecosystems. Proc Biol Soc Wash 96:379-391 